\title{
MANAJEMEN JARINGAN KOMPUTER DENGAN MENGGUNAKAN MIKROTIK ROUTER
}

\author{
Gusti Maharanda ${ }^{1}$ maharandagusti@gmail.com
}

\section{Prodi teknik informatka universitas lancing kuning pekanbaru,Riau}

\author{
Jln yos sudarso no,km 8 umban sari Rumbai,pekanbaru
}

\begin{abstract}
Studi ini dimulai dari membuat observasi atau pengumpulan data tentang kondisi jaringan komputer di dalam distribusi bandwidth dan autentication. Pada tahap pengujian, menggunakan simulasi dengan 3 pengguna dalam infrastruktur dan ad-hoc. Otentikasi pengguna Hotspot digunakan untuk membatasi jumlah pengguna yang menggunakan fasilitas wireless. Kecepatan akses internet menjadi lebih cepat dengan distribusi bandwidth yang adil bagi pengguna. Mikrotik adalah sistem operasi yang handal, bukan hanya karena data keamanan yang sulit untuk menembus, tapi juga router dapat digunakan untuk kantor, kafe, dan lain-lain. Dengan manajemen penggunaan hotspot, akan mempercepat pengguna untuk melakukan kegiatan mereka dengan bandwidth besar yang cukup besar.
\end{abstract}

Kata kunci : Jaringan komputer, manajemen bandwidth dan routing.

\begin{abstract}
This study starts from making observations or collecting data about the condition of computer networks at the Faculties in the distribution of bandwidth and autentication. At the testing stage, it uses a simulation with 3 users in infrastructure and ad-hoc. Hotspot user authentication used to restrict the number of users that use wireless facilities. Speed Internet access becomes faster with the fair distribution of bandwidth for users. Mikrotik is a reliable operating system, not only because safety data are difficult to penetrate, but also router can be used for offices, cafes etc. With the hotspot usage management, it will speed up users to conduct their activities with a large bandwidth which is large enough.
\end{abstract}

Keywords : Network computer, management bandwidth and routing.

\section{LATAR BELAKANG}

Router berfungsi sebagai jembatan antara 2 jaringan (network), sehinggadapatberinteraksi tanpa harus mengganti alamat IP salah satu network-nya. Ada dua jenis router yaitu berupa perangkat keras dan perangkatlunak.
Perangkat lunak router, yang sering disebut dengan Router OS, merupakan system operasi yang digunakan administrator untuk mengatur jaringan, jalur perjalanan data, user, monitoring trafik dan penanganan apabila terjadi kesalahan pada jaringan komputer. 
Dalam aplikasi, router $O S$ diinstallkan pada sebuah komputer.

Masalah umum yang biasanya terjadi dalam sebuah jaringan komputer adalah menumpuknya jumlah pengguna yang menggunakan jalur yang sama. Apabila tidakada pengaturan, ibarat sebuah jalan, maka akan terjadi kemacetan sehingga semua pengguna tidak bisa mengakses tujuan sama sekali. Masalah lainnya adalah masalah penggunaan jaringan oleh orang yang tidak berhak. Maka perlu ada mekanisme otentikasi untuk menyaring agar pengguna yang sudah terregistrasi saja yang dapat mengaksesnya.

Penelitian ini dicoba mengenai manajemen jaringan komputer tersebut dengan menggunakan salah satu router OS yang ada yaitu Mikrotik Router. Dengan tujuan sebagai berikut :

1. Untuk mengatur dan mengetahui alokasi Bandwidth untuk akses jaringan local dan internet pada client dalam sebuah jaringan komputer.

2. Untuk melakukan pengelolaan (manajemen) penggunapada wireless access point (hot spot).

\section{TINJAUAN PUSTAKA}

\section{Mikrotik Router OS}

Mikrotik RouterOS ${ }^{\mathrm{TM}}$, merupakan sistem operasi Linux base yang diperuntukkan sebagai network router. Didesain untuk memberikan kemudahan bagi penggunanya. Administrasinya bisa dilakukan melalui Windows application (WinBox). Selain itu instalasi dapat dilakukan pada sebuah Personal Computer (PC). PC yang akandijadikan router mikrotik pun tidak memerlukan resource yang cukup besar untuk peng- gunaan standard, misalnya hanya sebagai gateway. Untuk keperluan beban yang besar (network yang kompleks, routing yang rumit dll) disarankan untuk mempertimbangkan pemilihan resource PC yang memadai. Fasilitas pada mikrotik antara lain sebagai berikut :

\section{a. Management Bandwidth \\ b. Statefull firewall \\ c. HotSpot for Plug-and-Playaccess \\ d. remote winbox GUI admin \\ e. Routing}

Mikrotik adalah sebuah perangkat lunak yang termasuk dalam Open Source system namun bukanlahfree software, artinya pengguna harus membeli licensi terhadap segala fasiltas yang disediakan. Free trial hanya untuk 24 jam saja. Pengguna bisa membeli software mikrotik dalam bentuk CD yang diinstall pada Hard disk atau disk on module (DOM). Jika pengguna membeli DOM, tidak perlu menginstall perangkat lunak pada PC yang akan dipakai tetapi tinggal menancapkan DOM pada slot IDE PC.

Mikrotik sekarang ini banyak digunakan oleh ISP, provider hotspot, ataupun oleh pemilik warnet. Mikrotik OS menjadikan computer menjadi router network yang handal yang dilengkapi dengan berbagai fitur dan tool, baik untuk jaringan kabel maupun wireless.

\section{Routing}

Routing adalah proses membawa packet data dari satu host ke host yang lain tetapi berbeda subnet. Komputer A bergabung dengan jaringan 192.168.1.0/24 dengan nomor 192.168.1.3. Jika A ingin berhubungandengan B (via hub/switch) maka proses terjadinya hubungan sama seperti yang dibahas pada bab sebelumnya. Tetapi bila $\mathrm{A}$ 
ingin berhubungan dengan $\mathrm{C}$ yang berbeda subnet maka paket yang akan dikirimkan harus melalui R. Tugas melewatkan paket ini sering disebutsebagai "packetforwarding".

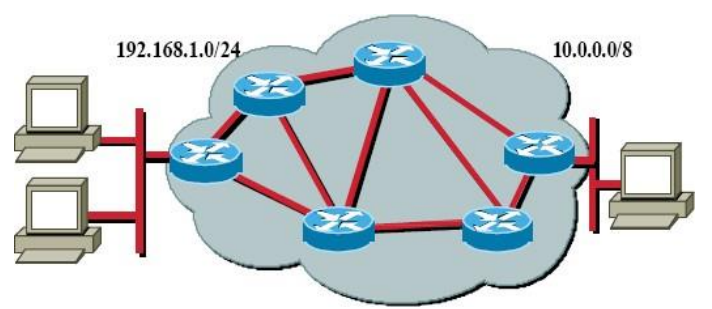

Gambar 1. Ilustrasi Jaringan Internet yang terdiri kumpulan router yang saling terhubung

Paket data dapat dilewatkan dalam sebuahjaringan komputer ataudi-routingkan oleh sebuah router dengan mengetahui

1. Alamat host tujuan paket

2. Informasi topologi jaringan dari router lainnya

3. Jalur yang mungkin dilalui oleh paket

4. Jalur terbaik untuk menuju ke alamat tujuan

5. Memelihara dan melakukan pengecekan terhadap informasi routing

\section{Static Routing}

Secara ilustrasi, static routing dapat digambarkan sebagai berikut :

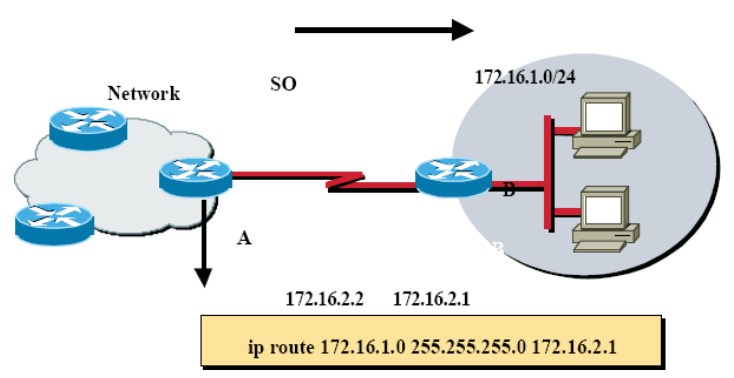

Gambar 2. Terapan static router B sebagai gateway

Gambar diatas menerapkan static routing, dimana jaringan dibawah router A apabila ingin menuju ke jaringan 172.16.1.0/24 harus melalui router B. Disini router B berfungsi sebagai gateway. Untuk memudahkan administrator yang menangani jaringan yang membutuhkan koneksi ke internet (sedangkan internet sendiri terdiri dari beratus-ratus nomor jaringan) maka biasanya digunakan default gateway.

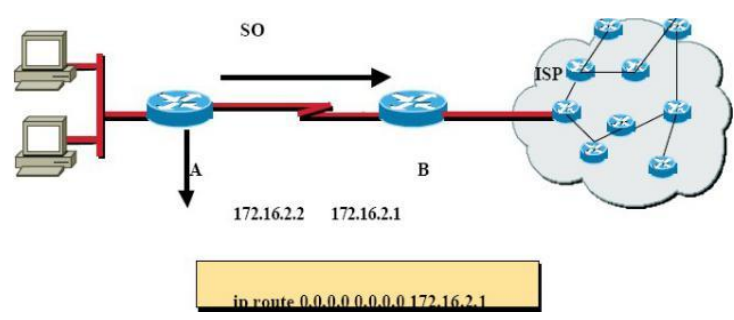

Gambar 3. Paket yang dikirim melalui default gateway router $\mathrm{B}$

\section{Manajemen Bandwidth}

Pengaturan bandwidth (bandwidth management) pada jaringan komputer diperlukan untuk mengatur tiap data yang lewat, sehingga pembagian bandwidth menjadi adil. Dalam hal ini Mikrotik RouterOs juga menyertakan packet software untuk megatur lebarmaksimumbandwidth yang diizinkan.

Trafik jaringan berhubungan dengan paket data yang dibangkitkan oleh kartu ethernet (NIC) pada komputer pengirim kemudian data ini akan diterima oleh kartu ethernet komputer penerima, kemudian teruskan oleh driver kartu ethernet (Network Driver) ke bagian kernel linux untuk diproses. Proses ini hanya mengatur paket data yang keluar maupun masuk melalui satu kartu ethernet. Kernel linux yang bertanggung jawab mengatur aliran data disebut kernel traffic control.

Komputer dengan Sistem Operasi linux yang dioperasikan sebagai gateway atau router memungkinkan aliran paket data dapat diatur secara bidirectional (dua arah) melalui 
NIC0 dan NIC1. Gateway linux dikonfigurasi untuk memisahkan trafik dari jaringan lain atau koneksi internet yang disediakan oleh ISP.Hubungan komputerklien yang dibagian NIC1 ke ISP dapat dikendalikan, misalnya bandwidth smtp di jatah 64Kbps, \& ftp mendapatkan bandwidth 10Kbps.

\section{PERANCANGAN SISTEM}

Secara garis besar jaringan komputer yang dibangun untuk keperluan penelitian ini dapat diuraikan sebagai berikut:jalurinternet yang berasal dari jalur utama (backbone) jaringan komputer UMS dimasukkan ke dalam komputer router. Dari komputer router ini kemudian bandwidth dibagi untuk dua kelompok client yaitu client static dan client dinamic. Untuk client static client dihubungkan pada switch hub yang terhubung dengan komputer router sedangkan client dinamic melalui wireless access point yang juga dihubungkan dengan switch hub tersebut. Desain konfigurasi jaringan komputer dapat dilihat pada gambar dibawah ini.

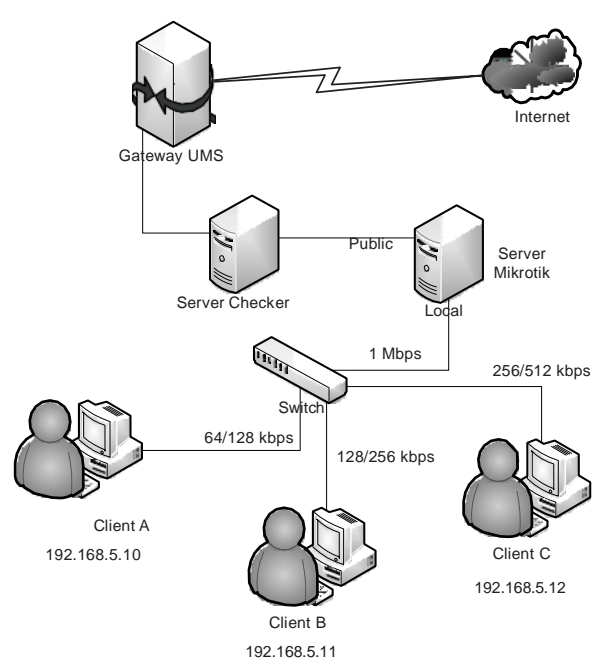

Gambar 4. Konfigurasi jaringan yang dipakai penelitian untuk client static

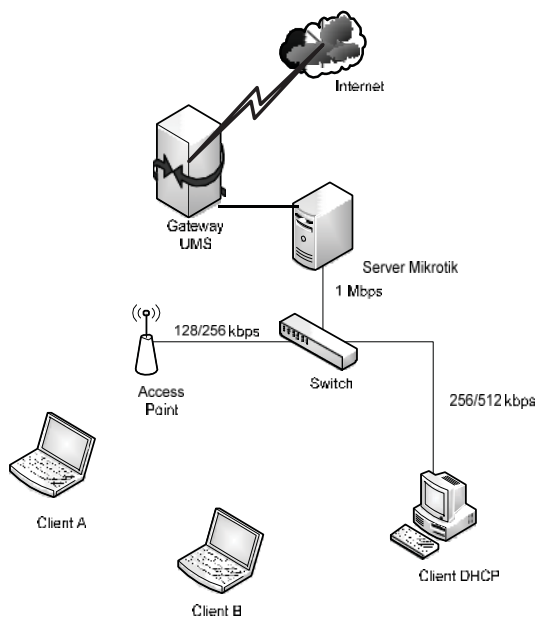

Gambar 5. Konfigurasi jaringan komputer yang dipakai penelitian untuk client dinamis

Komputer yang digunakan sebagai router mempunyai 2 buah kartu jaringan (Ethernet card) yaitu satu ethernet card (eth1) tersambung dengan jaringan luar(backbone jaringan computer UMS) dan satu ethernet card (eth0) terhubung dengan switch hub sebagai pembagi bandwidth untuk client. Secara umum susunan ethernet card dalam komputer router ini dapat digambarkan dalam diagram blok sebagai berikut:

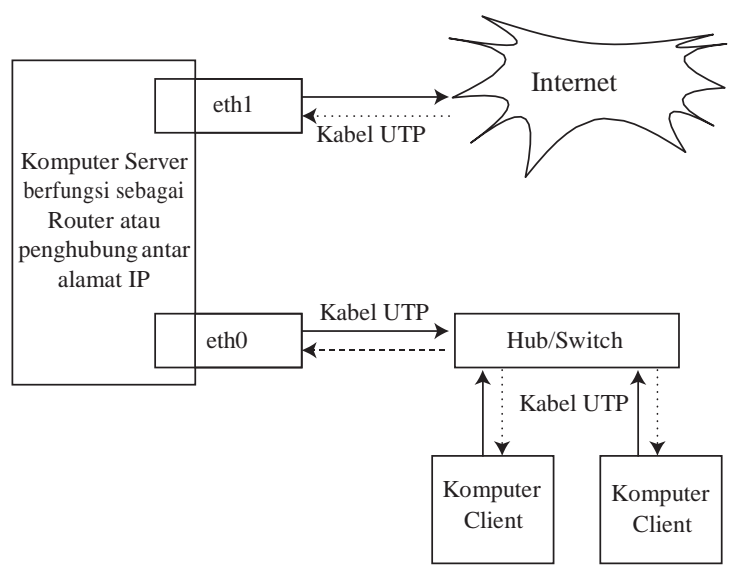

Gambar 6. Diagram blok fungsional pada komputer router

\section{Instalasi dan konfigurasi Perangkat Lunak}

Peneliti melakukan langkah pengaturan system dengan melakukan instalasi dan 
konfigurasi software yang dipakai yaitu MikrotikOS yang difungsikan sebagai router. Tahap awal adalah mendownload software Mikrotik Router OS dari internet. Karena file tersebut menggunakan format ISO maka langsung saja dibuat backup file tersebut pada CD dalam bentuk bootable disk yang akan digunakan dalam booting. Sebagai peringatan Mikrotik merupakan system instalasi individu sehingga tidak dapat digunakan dalam sistem dual booting sehingga berapapun besar kapasitas Harddisk yang dimiliki oleh komputer semuanya hanya akan di isi sistem dari mikrotik saja kecuali bila menggunakan software virtual PC.

\section{Langkah instalasi mikrotik router versi}

\subsection{6}

\section{a) Booting melalui CD-ROM}

Proses booting pada computer diatur di BIOS agar booting dilakukan lewat CD-ROM, kemudian tunggu beberapa saat di monitor akan muncul proses Instalasi.

\section{b) Memilih paket software}

Setelah proses booting akan muncul menu pilihan software atau paket yang mau di install, pilih esuai kebutuhan yang akan direncanakan. Paket yang tersedia di Mikrotik.

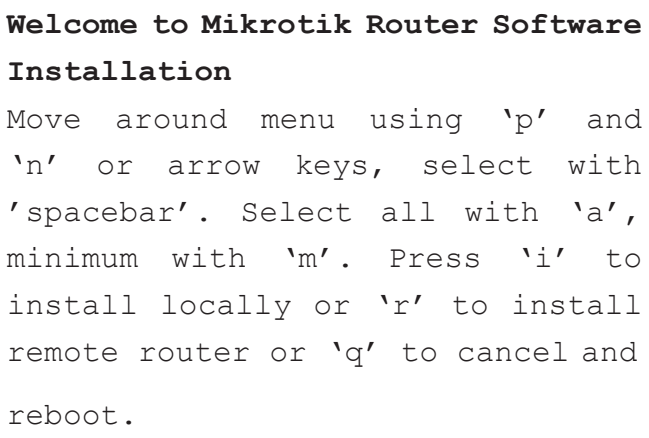

c) Instalasi Paket
Ketik "i" setelah selesai memilih software, lalu akan muncul menu pilihan seperti ini :

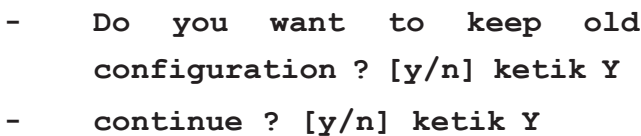

Setelah itu proses installasi sistem dimulai tidak perlu lagi mempartisi hardisk karena secara otomatis mikrotik akan membuat partisi sendiri.

\section{d) Proses Check system disk}

Setelah komputer booting kembali ke system mikrotik, akan ada pilihan untuk melakukan checksystem disk, tekan "y".

\section{e) Login Mikrotik router secara} Console

Konfigurasi Standar untuk mikrotik ada 2 model, yaitu model teks dan model GUI. Model GUI ada 2 juga, yaitu melalui Browser dan melalui Winbox. Penelitian ini menggunakan pengaturan dengan model teks (console) dan model GUI dengan winbox.

\section{Perintah Dasar}

Perintah mikrotik sebenarnya hampir sama dengan perintah yang ada dilinux sebab pada dasarnya mikrotik ini merupakan kernel Linux yang merupakan hasil pengolahan kembali Linux dari Distribusi Debian. Pemakaian perintah shellnya sama, seperti penghematan perintah, cukup menggunakan tombol TAB di keyboard maka perintah yang panjang, tidak perlu lagi diketikkan, hanya ketikkan awal nama perintahnya, nanti secara otomatis Shell akan menampilkan sendiri perintah yang berkenaan. Misalnya perintah IP ADDRESS di mikrotik. Cukup hanya mengetikkan IP ADD spasi tekan tombol $\mathrm{TAB}$, maka otomatis shell akan mengenali 
dan menterjemahkan sebagai perintah $I P$ ADDRESS. Setelah login, cek kondisi interface atau ethernetcard. Melihat kondisi interface pada Mikrotik Router

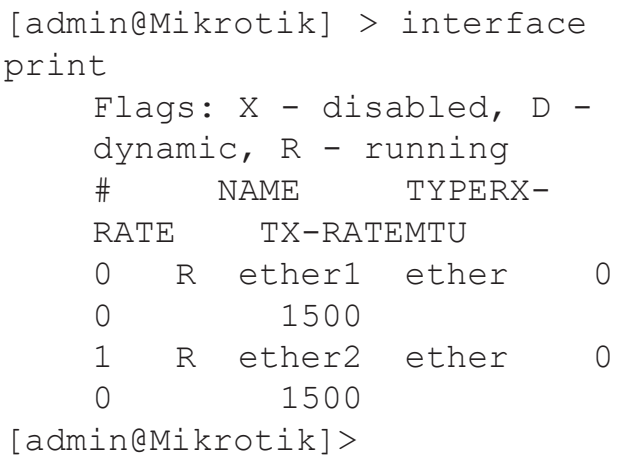

Jika interface terdapat tanda X (disabled) setelah nomor $(0,1)$, maka periksa lagi etherned cardnya, seharusnya R (running).

Cek lagi apakah nama interface sudah diganti.

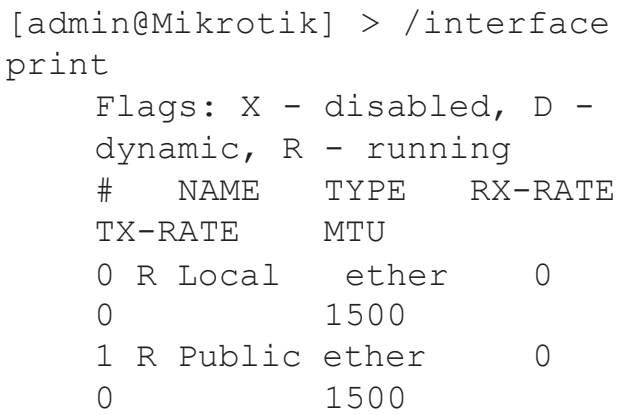

Baik dengan menggunakan model teks lewat console maupun melalui GUI winbox, pemakai dapat mengkonfigurasi fasilitasfasilitas mikrotik router diantarnya konfigurasi Ip Address, DHCP Server, konfigurasi hot spot, Network Address Translation (NAT), dan bandwidth management.

\section{PENGUJIAN DAN ANALISA}

Jaringan internet yang dipakai untuk pengujian adalah jaringan computer backbone UMS. Ada sebuah computer (PC) yang difungsikan sebagai router yaitu dengan menggunakan Mikrotik Router OS dan 3 buah client yang disimulasikan sebagai client pengakses internet. Konfigurasi susunan client dan PC router dengan Mikrotik Router OS dapat dilihat pada gambar di bawah ini:

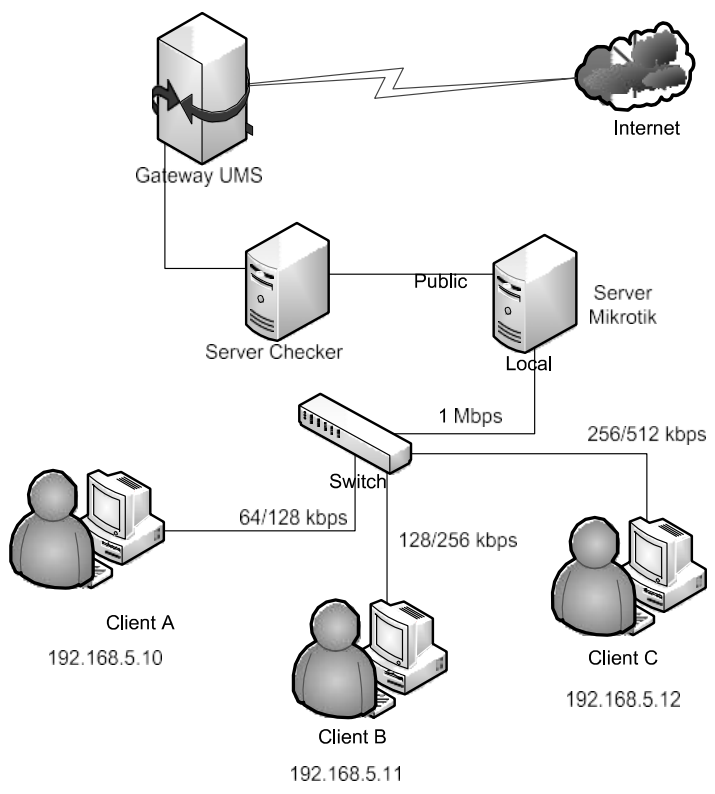

Gambar 7. Susunan jaringan computer dalam pengujian di FT. UMS

\section{Pengujian fungsi Bandwidth limiter}

Pengujian yang pertama yang dilakukan adalah fasilitas mikrotik router yaitu pembatas bandwidth (bandwidth limiter). Komputer yang berfungsi router mempunyai 2 buah Ethernet card yang satu terhubung dengan jaringan computer UMS dan yang satu lagi terhubung dengan switch hub yang selanjutnya dihubungkan dengan ke-3 buah client yang ada. Bandwidth yang diizinkan untuk masing-masing client dibuat berbeda seperti yang dilihat pada gambar diatas. Alamat internet (Ip Address) pada Ethernet card 1 dan 2 dibedakan kelasnya supaya lebih jelas pemilahannya. Peneliti memberikan alamat padaEthernet card 1 (alamat "public") sesuai dengan alokasi yang disediakan untuk Laboratorium Komputer FT UMS adalah 10.1.247.20 sedang alamat Ethernet card 
kedua (alamat "local") dibuat dalam daerah kelas C yaitu 192.168.5.1. Alokasi alamat pada computer client juga pada daerah kelas $C$ yaitu 192.168.5.10 (untuk client A), 192.168.5.11 (untuk client B), dan 192.168.5.12 (untuk client C).

Mikrotik Router OS mempunyai fasilitas untuk mengatur bandwidth client sehingga memungkinkan alokasi yang ber- beda bagi masing-masing client yaitu sebagai berikut: pada alamat user 192.168.5.10 diberikan bandwidth in sebesar $64 \mathrm{kbps}$ sedang bandwidth out sebesar $128 \mathrm{kbps}$. Alamat user 192.168.5.11 diberikan bandwidth in sebesar 128 kbps sedangkan bandwidth out sebesar 256 kbps dan terakhir alamat user 192.168.5.12 diberikan bandwidth in sebesar $256 \mathrm{kbps}$ sedang bandwidth out $512 \mathrm{kbps}$.

Tabel 1. Keterangan prototype

\begin{tabular}{llllll}
\hline Gateway & Interface & IP Address & IP Client & Bandwidth in & Bandwidth out \\
\hline 10.1.1.20 & Public & 10.1 .247 .20 & & & \\
& Local & 192.168 .5 .1 & 192.168 .5 .10 & $64 \mathrm{kbps}$ & $128 \mathrm{kbps}$ \\
& & & 192.168 .5 .11 & $128 \mathrm{kbps}$ & $256 \mathrm{kbps}$ \\
& & & 192.168 .5 .12 & $256 \mathrm{kbps}$ & $512 \mathrm{kbps}$ \\
\hline
\end{tabular}

Tabel diatas merupakan jenis pengaturan yang dilakukan untuk memberikan jatah bandwidth pada tiap PC user melalui mikrotik. Pada kenyataannya dalam memonitoring bandwidth tersebut tidak bisa maksimal seperti yang telah diberikan dalam pengaturannya, dikarenakan jumlah pengguna bandwidth yang dari server seharusnya 1 Mbps harus dibagi pada sejumlah $P C$ user sehingga terkadang bisa maksimal terkadang juga kecepatan access sangatlah lamban. Pembagian bandwidth ini digunakan hanya untuk keperluan access ke jaringan WANatau internet.

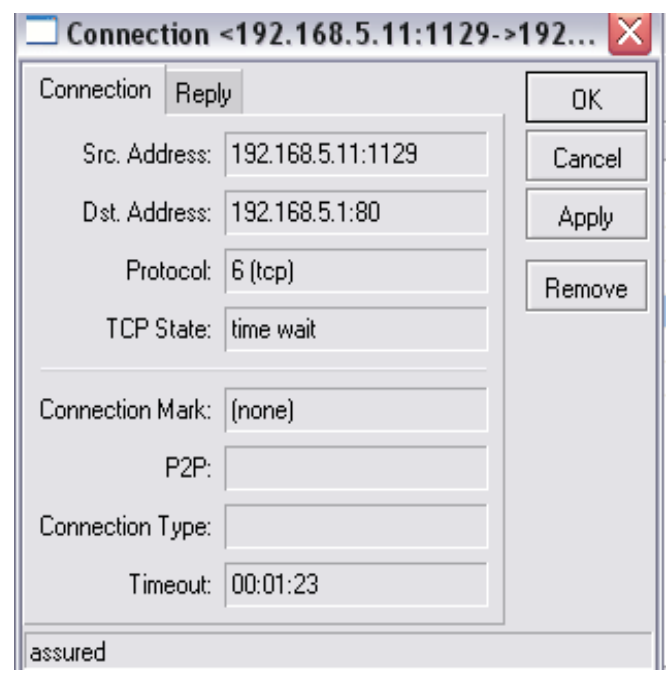

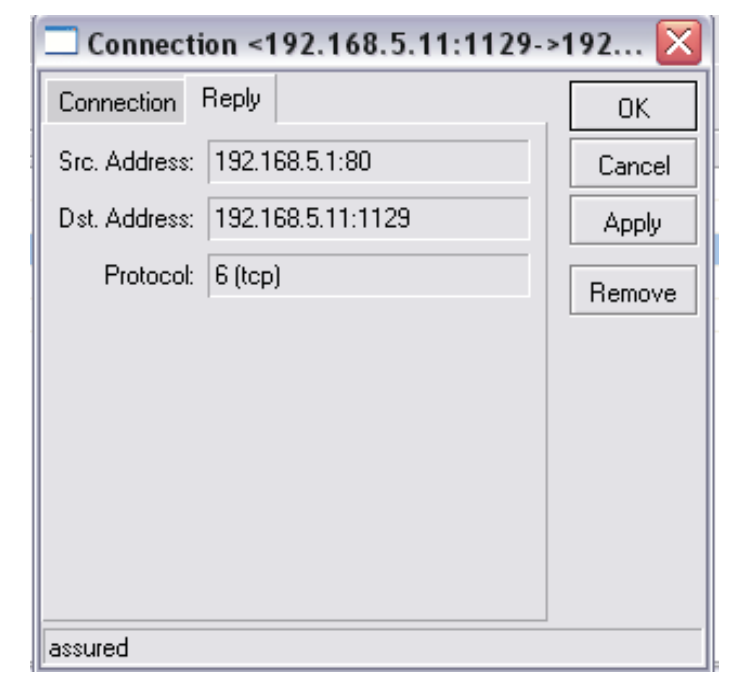

Gambar 8. Perjalanan alamat atau connection client pada alamat internet

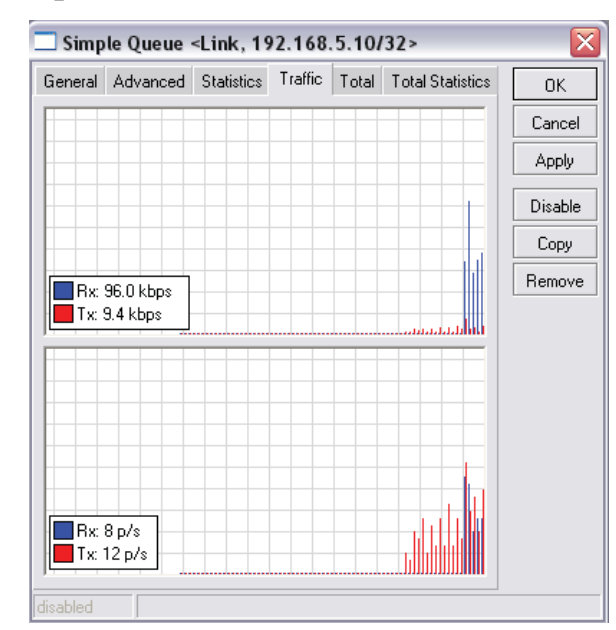




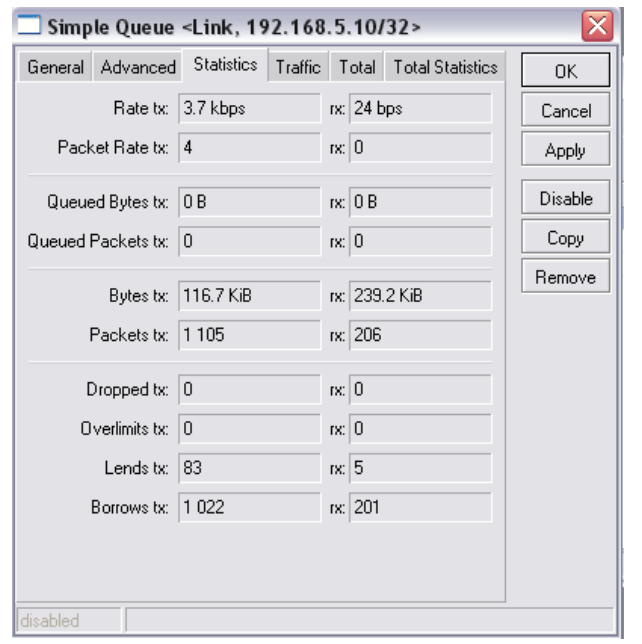

Gambar 9. Monitoring bandwidth meter dan statistiknya

\section{Hasil uji bandwidth limiter}

Pada tahap pengujian ini peneliti melakukan transfer data pada server menggunakan FilezilaFTP client. Dalam pengujiannetwork A alamat 192.168.5.10 dengan besar bandwidth
64/128 kbps, B alamat 192.168.5.11 dengan besar bandwidth 128/256 kbps dan C alamat 192.168.5.12 dengan besar bandwidth 256/512 kbps akan melakukan transfer data pada server secara bergantian. Selanjutnya network A, B dan C melakukan transfer data secara bersamaan.

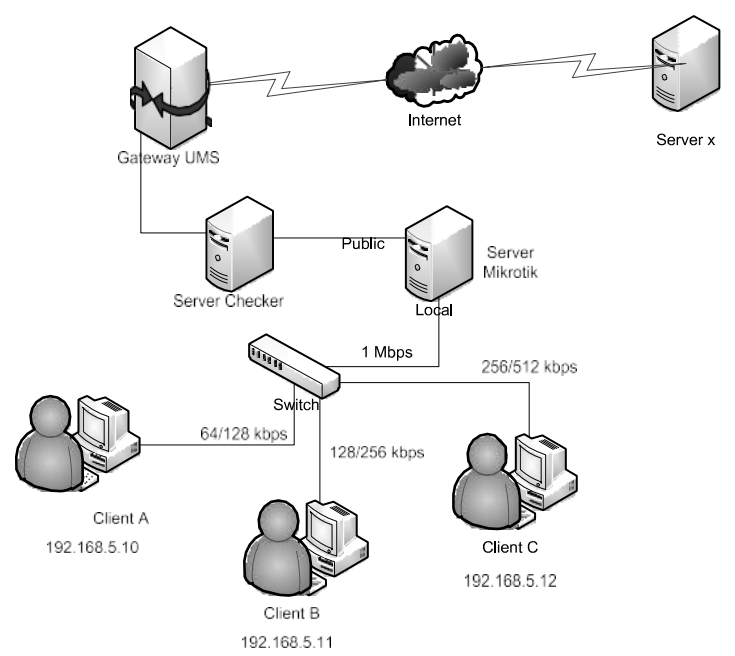

Gambar 10. Transfer data dari client pada server

Tabel 2. Hasil analisa bandwidth download per host

\begin{tabular}{cccccc}
\hline No & Sumber & Tujuan & $\begin{array}{c}\text { Bandwidth rata-rata } \\
\text { in/out }\end{array}$ & $\begin{array}{c}\text { Waktu } \\
\text { download }\end{array}$ & $\begin{array}{r}\text { Besar } \\
\text { data }\end{array}$ \\
\hline 1. & A & Server & $3.0 \mathrm{kbps} / 64.6 \mathrm{kbps}$ & 1.5 menit & $100 \mathrm{MB}$ \\
2. & & & $2.4 \mathrm{kbps} / 64.6 \mathrm{kbps}$ & 3.12 menit & $200 \mathrm{MB}$ \\
3. & B & Server & $4.4 \mathrm{kbps} / 128.7 \mathrm{kbps}$ & 0.78 menit & $100 \mathrm{MB}$ \\
4. & & & $4.2 \mathrm{kbps} / 128.6 \mathrm{kbps}$ & 1.5 menit & $200 \mathrm{MB}$ \\
5. & C & Server & $7.9 \mathrm{kbps} / 257.1 \mathrm{kbps}$ & 0.1 menit & $100 \mathrm{MB}$ \\
6. & & & $7.4 \mathrm{kbps} / 257.1 \mathrm{kbps}$ & 0.3 menit & $200 \mathrm{MB}$ \\
7. & A, B dan C & Server & $3.5 \mathrm{kbps} / 64.8 \mathrm{kbps}$ & 1.5 menit & $100 \mathrm{MB}$ \\
8. & & & $5.4 \mathrm{kbps} / 128.6 \mathrm{kbps}$ & 0.78 menit & $100 \mathrm{MB}$ \\
9. & & & $4.9 \mathrm{kbps} / 257.2 \mathrm{kbps}$ & 0.1 menit & $100 \mathrm{MB}$ \\
\hline
\end{tabular}




\section{Analisa bandwidth limiter}

Dengan menggunakan perhitungan manual didapat rumus :

$\frac{\text { Besar File }}{\text { Kecepatan acces transfer data }}=$ Sekian menit

1. Dengan adanya batasan sebesar $64 \mathrm{kbps}$ pada uji bandwidth di atas telahsesuai dengan ketentuan yang diberikan oleh server.

2. Ujibandwidth64kbps dengan melakukan download data sebesar $200 \mathrm{MB}$ telah sesuai dengan jatah yang diberikan,

3. Dengan adanya batasan sebesar 128 kbps pada uji bandwidth diatas telah sesuaidengan yang diberikan oleh server.

4. Uji bandwidth $128 \mathrm{kbps}$ dengan melakukan download data sebesar $200 \mathrm{MB}$ telah sesuai dengan jatah yang diberikan dan kecepatan waktu yang sesuai.

5. Dengan adanya batasan sebesar 256 kbps pada uji bandwidth diatas telah sesuai dengan yang diberikan oleh server, dapat diselesaikan dalam waktu yang cepat.

6. Uji bandwidth $256 \mathrm{kbps}$ dengan melakukan download data sebesar $200 \mathrm{MB}$ telah sesuai dengan jatah yang diberikan dan kecepatan waktu yang sesuai.

7. Ketika ke tiga network $\mathrm{A}, \mathrm{B}$ dan $\mathrm{C}$ bersamaan melakukan download data sebesar 100 MB maka penggunaan bandwidth yang telah diatur akan menjadi sangat sibuk sehingga kecepatan setiap data akan bergantian terus-menerus.

\section{Analisa manajemen user pengguna hotspot}

Pengujian dilakukan di Ruang Internet Perpustakaan Universitas Muhammadiyah
Surakarta. Peneliti membagi pengujian aplikasi ini berdasarkan hak akses user.

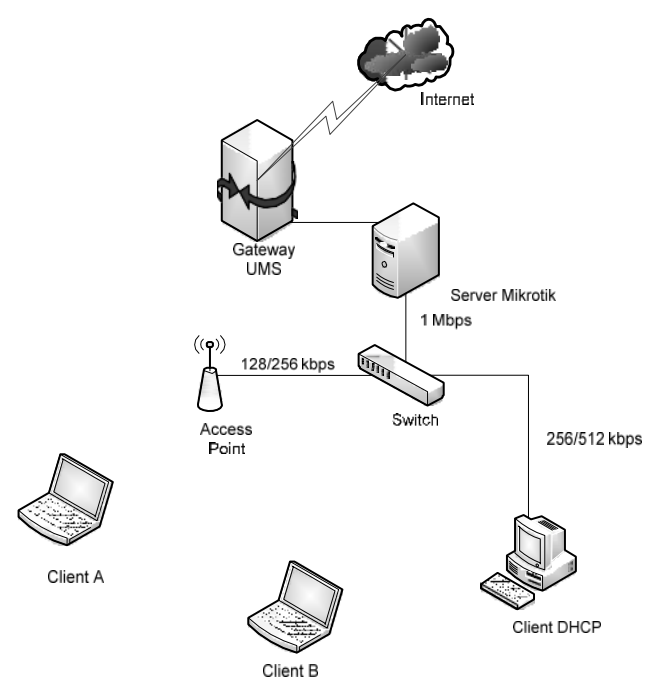

Gambar 11. Rancangan simulasi titik penempatan access point

\section{Hak Access Internet Pada Client}

Komputer client mengakses aplikasi yang berada di komputer server mikrotik melalui browser internet dengan alamat mikrotik. Disana client harus memiliki ijin penggunaan terhubung internet dari server. Dengan kata lain client yang mengingkan connection internet harus memasukkan username melalui "LOGIN=username" dan $P A S S W O E R D=$ sesuai yang diberikan server.

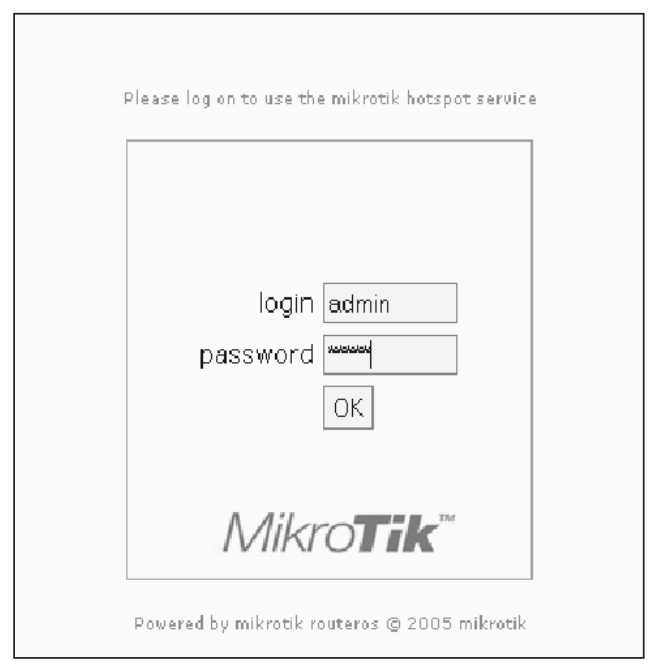

Gambar 12. Status mikrotik pada client 
Dengan adanya login seperti gambar diatas maka tidak semua client pengguna hotspot dapat terhubung dengan internet tanpa memiliki username untuk login dan password yang ditentukanolehadmin atau server. Dengan begitu admin mudah dalam membatasi client tanpa harus mem-filter satu per satu client yang ada atau pun secara menyeluruh semua client hotspot tidak dapat connect internet.

Setelah user memasukkan username pada login dan password dengan benar maka user mendapatkan tampilan seperti tampilan selamat datang dengan diikuti besar bandwidth dan juga waktu penggunaan user connect dengan internet.

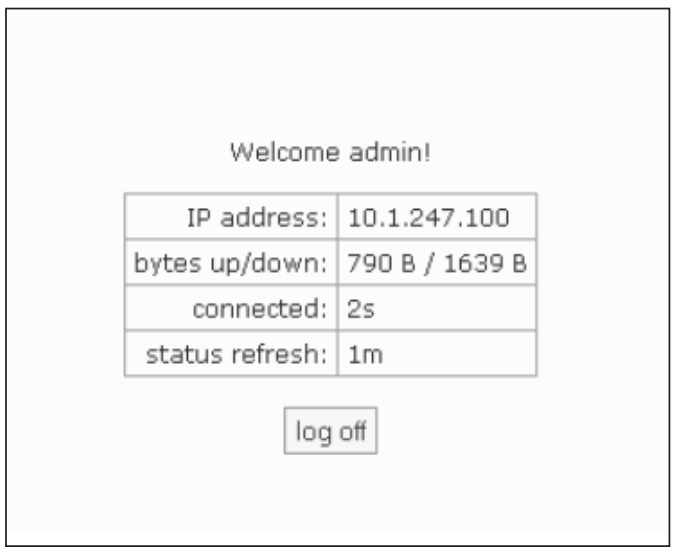

Gambar 13. Tampilan login user pada server mikrotik

\section{Kegagalan Client Dalam Melakukan Access Secara Local Maupun Internet.}

Kegagalan client dalam menggunakan hak access-nya dapat dikarenakan client tidak memiliki member atau username maupun password yang benar seperti yang telah diberikan pada server. Setiap client akan meng-access internet akan dipaksa masuk ke tampilan authentication yang telah disetting oleh admin, sehingga jika client belum menjadi member admin maka client tidak dapat meng-access internet. Member yang diberikan oleh server hanya untuk 1 user saja.

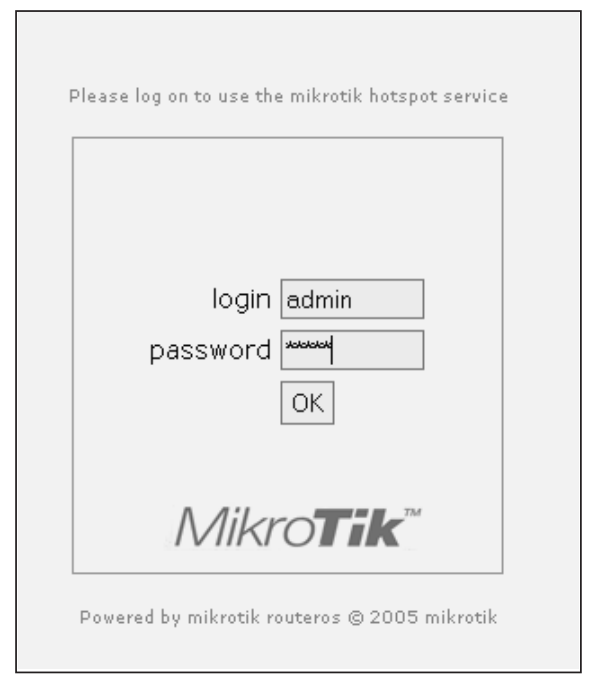

Gambar 14. Login user untuk meng-access internet

\section{Analisa User Hotspot}

Tabel 3. Hak access user per alamat

\begin{tabular}{lllllll}
\hline No & Alamat User & Mac address & Login & Password & Bandwidth dari server in/out & Bandwidth user \\
\hline 1. & 192.168 .5 .10 & 00-E0-4C-6D-65-F1 & D400030078 & Faria078 & $64 \mathrm{kbps} / 128 \mathrm{kbps}$ & $790 \mathrm{~B} / 1639 \mathrm{~B}$ \\
2. & 192.168 .5 .11 & 00-A5-8C-6B-45-G1 & D400030078 & Faria078 & - & \\
3. 192.168 .5 .11 & 00-A5-8C-6B-45-G1 & D400030049 & Arjuna049 & $64 \mathrm{kbps} / 128 \mathrm{kbps}$ & 790B / 1639B \\
4. 192.168 .5 .12 & A4-45-6B-D9-0C-13 & D400030090 & Mya090 & $64 \mathrm{kbps} / 128 \mathrm{kbps}$ & $790 \mathrm{~B} / 1639 \mathrm{~B}$ \\
\hline
\end{tabular}


1. User dengan alamat 192.168.5.10 dapat dengan benar memberika ijin "Login" dan "Password" pada server sesuai dengan data yang diberikan user kepada server bandwidth yang diterima user belum sesuai selama user hanya melakukan ijin masuk untuk dapat meng-access internet saja.

2. User dengan alamat 192.168.5.10 dapat dengan benar memberika ijin "Login" dan "Password" pada server sesuai dengan data yang diberikan user kepada server bandwidth yang diterima user belum sesuai selama user hanya melakukan ijin masuk untuk dapat meng-access internet saja.

3. User dengan alamat 192.168.5.11 tidak dapat melakukan access internet dikarenakan user dengan alamat 192.168.5.10 sedang melakukan access, jadi kode login dan password tidak dapat diulang kembali dalam waktu yang sama. Hal tersebut terjadi karena dalam system filter chain pada hotspot hanyamengijinkan 1 user sajayang boleh masuk dan mem-bypass semua aktifitas internet dan mengarahkannya pada alamat otentikasi yang dibuat.

4. User dengan alamat 192.168.5.11 dapat melakukan access internet karena mendapatkan ijin dari server sesuai dengan procedure yang berlaku untuk dapat melakukan access internet. Dengan username dan password yang berbeda tentunya.

5. User dengan alamat 192.168.5.12 dapat melakukan access setelah memasukan login dan password dengan benar, disini peneliti mengarahkan semua access internet yang terhubung secara $\mathrm{DHCP}$ server harus melalui tahap authentication tersebut.

\section{KESIMPULAN DAN SARAN}

\section{Kesimpulan}

Berdasarkan hasil pengujian dan analisa perancangan jaringan menggunakan mikrotik route, masih jauh dari sempurna. Dari hasil pengujian dapat disimpulkan bahwa :

1. Mikrotik router mampu melakukan management user pengguna hotspot, management bandwidth.

2. Server mikrotik dapat digunakan untuk mengatur routing static maupun dynamic.

\section{Saran}

Peneliti memiliki beberapa saran yang dapat digunakan sebagai bahan pertimbangan untuk penelitian berikutnya :

1. Kapasitas jaringan dapat dikendalikan oleh mikrotik artinya jaringan yang dibangun untuk jaringan local maupun internet dapat dikendalikan system dan aplikasinya oleh mikrotik sehingga tidak memberatkan kerja admin dalam mengawasi dan memperbaiki jaringan yang mengalami masalah.

2. Didalam membangun jaringan perlu adanya limitasi bagi para userpengguna hotspot, untuk membatasi jumlah pengguna supaya tidak terlampau banyak user yang melakukan access internet.

3. Management user sangat bermanfaat sekali bila diberlakukan dalam realitanya. Karena dengan memberikan management user pengguna hotspot tersebut, bandwidth dapat lebih terkondisikan karena tidak semua orang dapat melakukan access internet tanpa menjadi member pada admin atau server. 


\section{DAFTAR PUSTAKA}

Arinanto, Kurniawan Dwi, 2002,Wardriving Serangan Terhadap Wireless LAN, Program Magister Teknik Elektro, ITB, Bandung.

Kuntoro Priyambodo Tri, Heriadi Dodi, 2005, Jaringan Wi-fi, Yogyakarta : Penerbit Andi.

Muhammad, Reza, 2003, 15 Jenis Serangan Cracker, Artikel Populer Ilmu Komputer, www. ilmukomputer.com (diakses Juni 2008).

Mulyana, Eueung; Purbo, Onno W., 2000,'Firewall: Sekuriti Internet”, Computer Network Research Group, ITB, Bandung.

Neuman, Clifford B, 1993, Proxy-Based Authorization and Accounting for Distributed Systems, Proceedings of the 13th International Conference on Distributed Computing Systems, Pittsburgh, May, 1993.

Purbo, Onno W,2005. Buku pegangan internet wireless dan hotspot. Jakarta : PT. Elek Media Komputindo

.publikasiilmiah.ums.ac.id/xmlui/bitstream/handle/11617/1197/4_KomuniTi_Vol_2_No_2_Manajeme n\%20Jaringan_Sujalwo.pdf?sequence=1\&isAllowed=y

https://ojs.unsiq.ac.id/index.php/ppkm/article/view/437/266

https://www.neliti.com/publications/126034/sistem-manajemen-hotspot-di-politeknik-negeribanjarmasin-menggunakan-mikrotik-r

http://eprints.mdp.ac.id/770/1/JURNAL\%202008120001\%20Sapta Okta Fahlevi.pdf

https://ejurnal.teknokrat.ac.id/index.php/teknoinfo/article/view/121/91

http://e-jurnal.lppmunsera.org/index.php/jsii/article/view/70/66

http://smkmutupringsewu.sch.id/repos/e-books/jaringan/dewo bandwidth.pdf

Rahardjo, Budi, 2002, Kemanan Sistem Informasi Berbasis Internet, PT. Insan Infonesia, Jakarta.

Rpoix, 2003, Mikrotik OS untuk bandwidth, management, Artikel Populer Ilmu Komputer, www.ilmukomputer.com (diakses Juni 2008).

PP Putra, 2016, "Pengembangan Sistem Keamanan Jaringan Menggunakan Rumusan Snort Rule (Hids) untuk Mendeteksi Serangan Nmap."Satin 2(1). 